\title{
Equity Theory Based Strategies for Students on Overcoming Problems in Ph.D. Dissertation Committees
}

\author{
Dara Schniederjans \\ Rawls College of Business, \\ Texas Tech University, \\ Lubbock, TX, USA
}

dara.schniederjans@ttu.edu

\author{
Marc Schniederjans \\ College of Business \\ Administration, \\ University of Nebraska-Lincoln, \\ Lincoln, NE, USA
}

mschniederjans1@unl.edu

\author{
Yair Levy \\ Graduate School of Computer and Information Sciences, \\ Nova Southeastern University, Fort Lauderdale, FL, USA \\ levyy@nova.edu
}

\begin{abstract}
There exists a critical relationship between the professor chairing the Ph.D. dissertation committees and his or her Ph.D. students. When problems arise in a Ph.D. program, issues of fairness based on fundamental principles in equity theory can guide both the professor chairing dissertation committees and the student to a just resolution. This paper proposes equity theory as a guiding aid in Ph.D. program problem resolution. To further illustrate equity theory considerations, a series of actual case applications are presented as suggestions for potential strategies in dealing with problems in Ph.D. dissertation committees. We conclude with recommendations both for Ph.D. students and new or veteran dissertation committee members.
\end{abstract}

Keywords: Equity theory, Ph.D. dissertation problem solving, student fairness in doctoral studies, student-professor relationship strategies, conflict resolution in doctoral student-advisor relations.

\section{Introduction}

Material published as part of this publication, either on-line or in print, is copyrighted by the Informing Science Institute. Permission to make digital or paper copy of part or all of these works for personal or classroom use is granted without fee provided that the copies are not made or distributed for profit or commercial advantage AND that copies 1) bear this notice in full and 2) give the full citation on the first page. It is permissible to abstract these works so long as credit is given. To copy in all other cases or to republish or to post on a server or to redistribute to lists requires specific permission and payment of a fee. Contact Publisher@InformingScience.org to request redistribution permission.
Equity is the art of one individual being fair and impartial in social interactions with another individual (Adams, 1965). It is an art because it requires an individual to have a skill. The skill resists the ease that comes with selfish interests in order to facilitate an effective relationship with another individual's goals in mind. We are not suggesting equity in relationships result in one person's demise over another's success. This would be contrary to the idea of equity. Equity results in symbiotic rela- 
tionships that help both individuals. An example of this is 'Guanxi', which is a Chinese concept referring to relationship networks where individuals carry obligations to facilitate exchange of favors (Ambler, Styles, \& Xiucun, 1999; Leung, Heung, \&Wong, 2008; Lovett, Simmons, \& Kali, 1999). Therefore, equitable action toward one individual might reciprocate to the acting individual.

In doctoral programs, more so than in any other educational program, professor and graduate student interaction should be both consistent and as frequent as is necessary, whether working in a classroom seminar or on papers and/or research projects. In most cases, doctoral students are assigned to professors or advisors who are expected to aid them in day-to-day research training. The professional relationships that result from these interactions will help not only the doctoral students in their future careers, but also the professors in their growth as educators and researchers (Carter \& Whittaker, 2009). However, this is only the case when trust and equity are present (Chan, 2008). If an inequitable exchange results either from the professor's actions or the student's, it can be costly to a student's career. Inequity is costly to the student in terms of obtaining the doctorate from the institution, finding a job, ability to publish in a prestigious journal, or eventually receiving tenure or a permanent full-time position. With student dropout rates in doctorial programs estimated between 40 and 50 percent (Smallwood, 2004), relationship factors that can lead to keeping students in school are critical for students and faculty. Indeed, attrition rates in doctorial programs can negatively impact the professor's reputation and in some cases the institution's, school's, or doctoral program's reputation (McWilliam, Singh, \& Taylor, 2002; Smallwood, 2004). To overcome these potential negative outcomes it is important to understand how equity impacts relationships between doctoral students and professors chairing doctoral dissertations. It is also important to understand what makes an effective student-professor relationship in a Ph.D. program in maintaining equity in professional relationships.

\section{Literature Review}

\section{Equity Theory in Higher Education}

One way to understand an equitable relationship between a doctoral student and professor is to study the theory that underlies equity. One of the most explicit and rigorously developed models explaining how individuals evaluate social exchange relationships is John Stacey Adam's "Equity Theory" developed in 1965 (Cosier \& Dalton, 1983). Equity works like a system with inputs and outputs. Adam's (1965) "Equity Theory” describes what equity is in relation to a system. The inputs are factors that a person has accomplished (i.e., past experience, education, and work) and perceives to be worthy of some return. The outputs are the returns to the individual's job investment (Cosier \& Dalton, 1983). For example, Person p that has worked for a company for 40+ years and has helped to improve the reputation of that company views his work as an input. Whereas an output would be how person $\mathrm{p}$ is treated by his superior or how person $\mathrm{p}$ is compensated. In all of our cases, we will denote equity and inequity in the context of fair or unfair actions in treating other fellow human beings, rather than equity or inequity in the philosophical aspect of equal in terms of qualifications, status, and/or rank. Equity (i.e., fairness) and inequity (i.e., unfairness), are determined by the ratio between inputs and outputs. In a modeling context, inequity exists for Person (p) whenever he perceives the ratio of his outcomes (O) to inputs (I) and the ratio of other's (o) outcomes to other's inputs are unequal (Adams, 1965, p. 280). According to Adams (1965), inequity exists when either of these relationships holds true:

$$
\frac{O p}{T p}<\frac{O Q}{T O} \text { or } \frac{O p}{T p}>\frac{O Q}{T O} \text {. }
$$


Equity exists when:

$$
\frac{O p}{T p}=\frac{Q Q}{1 Q}
$$

Using the illustrative example provided in the preceding paragraph, if person $\mathrm{p}$ believes that his ratio between his outputs (i.e., working $40+$ years and helping to build the reputation of the company) and inputs (i.e., the treatment person p receives from his superior or compensation) is less than the ratio of other individuals outputs (i.e., the time or contributions of others in the company) to inputs (i.e. treatment others receive from their superior or their compensation) then there is an inequitable situation faced by person p. However, if the ratios are equal, than the situation faced by person $\mathrm{p}$ is equitable.

According to Adams (1965) there are four postulates when inequity exists: (1) when the perceived inequity creates tension in an individual, (2) when the amount of tension is proportional to the magnitude of the inequity, (3) when this inequity motivates the individual to reduce it, and (4) when the strength of the motivation to reduce the inequity is proportional to the perceived inequity. This equity theory has been tested and shown to be valid. In Wicker and Bushweiler (1970), as well as in Carrell and Dittrich (1978), subjects were found to prefer situations in which all inputs/outcomes ratios were equal. Also, the proposition that individuals cognitively distort inputs to achieve equity where necessary has also been supported (Carrell \& Dittrich, 1978; Leventhal, Allen, \& Kemelgor, 1969).

One complicating factor in equity theory and research is the difference in individuals' tolerance. Past literature shows some individuals have a higher tolerance for inequity than others (Tornow, 1971). That is, if inequity does exist and a person tolerates it, or does not commit to an action to reduce the inequity, then the inequity threshold will not be met for that individual. Many unethical people might take advantage of an individual with higher tolerance for inequity in order to satisfy their own interests. We call these people unethical, because an ethical situation is defined as the consequence of how an individual's moral decision affects the interests, welfare, or expectations of others (Brass, Butterfield, \& Skaggs, 1998; Rest, 1986). When unethical individuals are prevalent it can often permeate an entire organization and have negative consequences. Additionally, it is evident that some individuals are habitual when it comes to being unethical and taking advantage of other individuals. Such individuals appear to contagiously thrive on inequity, thus, taking advantage of their position for personal gains.

\section{Argumentation Theory}

Argumentation theory has been developed over decades of research (Driver, Newton, \& Osborne, 2000). Toulmin (1958) in his book, The Uses of Argument, presented a model that defines the elements of argumentation including data, claim, warrants, and backing. Data are the facts in support of a claim (Driver et al., 2000). The claim is the conclusion whose merits are established (Driver et al., 2000). Warrants are the reasons to justify the connections between the data and the claim (Driver et al., 2000). And the backings are the basic assumptions that provide justification for the warrants (Driver et al., 2000).

The basic four point structure of the arguments model (which will be used in the case studies) is as follows: Because (the data)...since (the warrant)...on account of (the backing)...therefore (the conclusion) (Driver et al., 2000). Despite this being the basic structure, arguments can be presented in various ways including the backing coming after the conclusion, which is how we present our arguments in this paper. In reality, as long as the argument is relevant, sufficient, and acceptable (Blair \& Johnson, 1987) the organization is not as important. In this paper, we use argumentation theory for dealing with inequality issues among students and their professors. 


\section{Inequity in Professor-Student Relationships}

Universities with a few unethical individuals who exploit others (e.g., doctoral students) for their own selfish interests can be detrimental to the exploited and to the university in its entirety. A ripple effect may derail the reputation of program and the institution as a whole. For doctoral students and university administrators, it is important to identify these individuals and know how to deal with them. To do this, one should be aware of what makes an effective relationship between a professor and a doctoral student. For the benefit of students who might be faced with a situation of inequity, we will discuss what makes an efficacious student-professor relationship.

Graduate student and professor relationships are complex (Grover, 2007). In some cases doctoral students are treated more like colleagues than actual students. If the professor treats the student equitably, the relationship can foster into a partnership that can help the student and the professor gain publications, contacts, research grants, and opportunities. Yet, if the professor is inequitable in the treatment of the student, this can severely damage both the professor and student, especially if the student works to alleviate the inequity. Another situation can exist in which the student, despite being treated inequitably, does not try to correct the situation. In this case where the student is taken advantage of by the professor, it often involves the positional power of the professor in their relationship.

Graduate students sometimes ignore the fact they are being treated inequitably because they view the professor as having power over them (e.g., professor's power to grant or not grant their degree). Blevins-Knabe (1992) suggested that part of the role of a professor is power inherent in the professor-student relationship. Paludi (1990) and Zalk, Paludi, and Dederich (1990) suggested that this power comes from the professor evaluating the student and having the authority in the subject in which the professor is expert. There are few individuals who have the bravery to stand up to someone who can "make or break" their careers. Those individuals that do stand up against inequity may be heroes to those who follow, but are often hurt in the process, which is an inequity in and of itself.

What constitutes a fair and equitable relationship with a professor? Blevins-Knabe (1992) provided a list constituting what a professor's role should be toward students. First, professor's role should be teaching, not only the course material, but also modeling how to use the knowledge appropriately. Second, being trustworthy in offering faculty members sensitive information, including objective and equitable evaluation as well as equal learning opportunities for all students without preferential treatment. Finally, the professor's role should include demonstrating power in the authority of the subject matter.

Schniederjans (2007) proposed a Ph.D. student bill of rights that dealt with issues regarding what Ph.D. students should expect from professors who chair their doctoral committees. This bill of rights contains a few requirements for both faculty members and students, including:

1. Faculty members should make sure the right to select Ph.D. program committee members is given to the student;

2. The student should be given the right to permit changes in the program committee either before or during the creation of the dissertation;

3. A committee chair should work with the student on research prior to, during, and after the dissertation;

4. A committee chair should set up codes of conduct between the student and the chair based on sound ethical values.

These are the rights a doctoral student should have and a committee chair should ensure. If the program committee chair fails to ensure these fundamental rights, a student will most likely have problems. As Johnson (2010, p. 190) suggested, faculty members should act as a guide, role 
model, and instructor to less experienced students. Faculty members should also provide the student with knowledge, advice, challenge, counsel, and support in the pursuit of becoming a part of the profession (Johnson \& Huwe, 2003; Kram, 1985). These rights are critical success factors in ensuring equitable treatment.

Despite most professors being aware of what constitutes an effective relationship, one half of both undergraduate and graduate students reported the existence of significant negative events in their experiences with a professor or mentor (Kalbfleisch, 1997). Examples of such significant negative events include the mentor requesting burdensome help with projects, requesting assistance with issues beyond the scope of the doctoral research, disagreeing with the student beyond a reasonable scholarly debate, becoming angry with the student, discounting the student's ideas, being negatively critical of the student's work, neglect, and mentor incompetence (Johnson, 2010, p. 204). This is not to say that a professor does not have a responsibility to critically evaluate a doctoral student's work. Rather, it is to say that along with this responsibility for critical evaluation is a corresponding responsibility for professionally mentoring the student.

\section{Consequences of Inequity}

Negative consequences occur when people believe they have been inequitably treated. Law suits have brought dramatic changes to universities such as the University of Michigan, which was sued for giving unfair advantages to minorities in their undergraduate school (Sanchez, 1997). More recently a graduate student sought to sue Augusta State University for threatening to expel her for her beliefs on homosexuality (Miller, 2010). Other negative outcomes besides lawsuits include grievances, turnover, absenteeism, and deliberate, low productivity (Cosier \& Dalton, 1983; Dalton \& Todor, 1982; Locke, 1976; Mobley, Griffeth, Hand, \& Meglino, 1979; Muchinsky, 1977; Muchinsky \& Tuttle, 1979; Porter \& Steers, 1973; Steers \& Rhodes, 1978). Given that inequity can be a major problem in organizations of all kinds, including educational institutions, it makes sense that members of universities consider equitable treatment of individuals to be an important organizational goal (Carrell \& Dittrich, 1978).

Still the question remains: why care about the equity between a student and a professor in doctoral studies? As previously stated, when students believe that their inputs exceed the outputs of their efforts, they will work to resolve the inequity. Some do so with a passive aggressive mentality. An example of this occurs when the student diminishes inputs (i.e., doing less high quality research) in order to maintain a balance with the outputs. This behavior is referred to as "static equity theory” (Cosier \& Dalton, 1983). This is a relatively common consequence of inequity (Homans, 1961; Patchen, 1961). Other studies have shown dropping out of school to be another consequence (Carrell \& Dittrich, 1976; Telly, French, \& Scott, 1971). Dropping out occurs in an academic sense when a student does not finish his or her degree.

These inequitable consequences are severely limiting for the student. Not only are the students not living up to their potential, but they also are limiting the choices in getting out of the inequitable situation. By not producing as much research or achieving high academic marks, they hinder the opportunities to obtain a position at a university. This would also hurt the long-term reputation of the university in that the professor might not only be inequitable to a particular student, but also to many others in the course of his or her academic career. The problems with inequity can lead to individuals reducing the work to solve an inequity (Adams, 1965; Carrel \& Dittrich, 1978; Cosier \& Dalton, 1983) and even to a loss of self-efficacy (Nesbit \& Burton, 2006). However, some students may decide to do exactly the opposite. Instead of minimizing efforts, they will actually redouble them in order to impress the professor (Cosier \& Dalton, 1983). While this may or may not improve the outputs by the students' extra effort, the margin between the inputs and outputs will either be the same or larger. 
Another possibly damaging effect of redoubling efforts is the student's mental/physical health. Going through a doctoral program is a stressful situation. If a student has the added pressure of experiencing inequity with a professor or the dissertation chair, this can affect his or her mental or physical health in a negative fashion. Establishing a peer doctoral group of students with whom troubled students can share their experiences and voice their frustration is a viable option to assist in mitigating some stressful situations. Unfortunately it does not appear to completely eliminate such stressful situations. Given the potential impact on health, the stress might inhibit the student's ability to perform educational tasks in an effective manner.

In this paper, we use "argumentation theory” (Levy \& Ellis, 2006; Williams \& Colomb, 2003) as a framework for dealing with inequality issues (Adams, 1965; Carrel \& Dittrich, 1978; Cosier \& Dalton, 1983; Nesbit \& Burton, 2006). Using argumentation theory, we set forth a "problem" doctoral students face, which is then addressed by our "claim" or "strategy" that seeks to resolve the problem. We use a series of small case situations to present the use of this theory. The cases that follow highlight specific situations dealing with inequity between professors and graduate students. Each discusses how this inequity has been (or might be) resolved. This paper adds to current literature by analyzing cases of inequity and suggesting equitable approaches for doctoral program problem solving strategies.

\section{Case Study Problems and Strategies}

\section{Ph.D. Faculty Committee and Student Role Assumptions}

We assume in this paper that once a Ph.D. dissertation is established, the faculty that make up a committee invariably sign on with the understanding they should work with the students in a timely fashion to help them achieve their degree. We are also building our discussion here on the foundation that students are working in good faith in preparing their doctoral dissertation. As previously mentioned, faculty member roles are multi-faceted and faculty should try to assist students in many ways to help them earn their degrees. This assistance may include mentoring, supporting, encouraging, as well as helping them set realistic goals and timelines for completion.

We also assume no student can ever be assured he or she will obtain a degree simply by being admitted into a Ph.D. program. The hurdles of course work, comprehensive exams, and the dissertation each pose major obstacles that students must overcome in order to achieve a Ph.D. Failure in anyone of these hurdles can cost students their degrees. The expectation of success is set by the professor chairing the Ph.D. committee. It is assumed the student will work closely with the dissertation committee, particularly the dissertation chair of the committee.

Regardless of the best efforts from both faculty members, students, and their willingness to work together, students and dissertation committee members can face challenges that require resolution. What follows are a series of actual case situations where Ph.D. students reported to us problems they faced with their dissertation committees. These particular cases were selected based on commonly reported problems in the literature (Cassuto, 2010) and ideas suggested in the development of doctoral programs (Shambaugh, 2000). The suggested strategies (in some cases applied) are offered here as possible aids to future Ph.D. students who may confront similar situations.

\section{Case A: The Too Busy Dissertation Chair}

Problem: A student reported that his dissertation chair, in his opinion, was taking an excessive amount of time (i.e., three months) to read a set of three introductory chapters in his dissertation. When the student eventually met his dissertation chair to obtain whatever revised chapters he could, the dissertation chair accused the student of needlessly harassing and pushing too hard 
with regard to reviewing the dissertation. The dissertation chair indicated he would get to the revisions when he could, but that the student would just have to wait. The response was viewed as frightening for the Ph.D. student who believed at the professor's current rate, the student would never be able to stay on schedule for completion of his degree given the expected time schedule. The student and the dissertation chair had previously discussed timelines regarding degree completion goals, and the dissertation chair generally agreed to these goals when the dissertation plan was set up several years prior.

Claim: This is an inequitable situation for the student because the dissertation chair has failed to communicate in a timely fashion the progress (or lack thereof) he has had in reviewing any of the student's dissertation chapters.

Resolution: To resolve this problem, the student was advised to discuss the matter with the dissertation chair very diplomatically by first apologizing for the (perceived) aggressiveness in trying to move the progress of the dissertation along faster than the chair was able to comply. In addition, it was suggested the student remind the dissertation chair of the prior agreed upon timeline for expected completion of the Ph.D. program. This would communicate a justification (an equitable justification) for his timing concern regarding completion of his degree.

In this situation, the discussion with the dissertation chair resulted in the student becoming aware that the dissertation chair was overworked (due to a variety of tasks placed upon him in recent months). The dissertation chair agreed to work with the student to come close to the timeline goals, but stated he required several additional weeks to complete the dissertation review process.

Advice: It is a difficult balancing act to know how far a Ph.D. student can push committee members or the dissertation chair who reads and edits a dissertation. Timelines for the dissertation should be set well in advance, but with some flexibility. It is also advisable to be diplomatic in exchanges with dissertation committee members on timeline issues. The more the timeline is shared and agreed upon by committee members and the student, the more likely it is everyone will comply. Students should also be aware that at most universities, Ph.D. committee members are not directly compensated for their work on Ph.D. committees, and most faculty members volunteer their time and expertise to help students largely at their own expense. At some universities the assignment of faculty member to Ph.D. committees is made in such a way that it does not consider the workload of the faculty member. This can result in a substantial workload for committee members. Students should be advised to select committee members who are willing and have the time to help them in their degree programs, while also communicating with previously graduated students from that Ph.D. program who can testify about the timeliness of a specific dissertation committee chair and/or members.

Based on argumentation theory, our argument for this case is as follows: because the dissertation chair was taking three months to review introductory paragraphs to the student's dissertation and since the student was frightened by the professor's reaction to his inquiry, this was an inequitable situation for the student. Yet, because the dissertation chair felt harassed and since dissertation chairs kindly volunteer their time and expertise to students often at the expense of a dissertation chair's time, the student is advised to communicate and choose dissertation chairs who have the time to devote to the student. Students also need to be aware that any professor's time commitments can vary.

\section{Case B: The Non-Legible and Unfocused Feedback Dissertation Chair}

Problem: A Ph.D. student was working on her dissertation where the feedback provided by her dissertation chair was both non-legible and unfocused. First, the dissertation chair provided his comments to the student using non-legible cursive hand-written feedback. This was a particular 
problem because the student is a recent immigrant and English is her second language. Additionally, when the feedback was interpreted, it was a mere set of statements pointing to various disagreements with the text in the draft, without providing guidance of how to fix, focus, or change the draft so it could be improved or be better focused. At times, when the feedback was provided it was directly conflicting with the feedback provided by that dissertation chair in prior feedback, reverting back to the same way it was prior to the adjustments made following earlier feedback (this can be characterized as 'ping-pong' feedback).

Claim: This is an inequitable situation for the student, especially for students for whom English is a second language, because the role of the dissertation chair is to provide feedback that is clear and instructively helpful to the student to focus her work.

Advice: In this situation, the student was advised to approach the dissertation chair and request scheduled meetings to discuss the feedback provided. Prior to such meetings, the student sought the help of a family member who is native English speaking to interpret the professor's cursive handwriting feedback. Students who do not have such personal help might consider asking for help from other appropriately skilled Ph.D. students for interpretation help or consider using the services of writing labs, which are available in most universities. In this case, the student typed the feedback and brought it with her to the meetings with the dissertation chair, where she sought clarifications to resolve conflicting feedback and avoid the 'ping-pong' effect.

Based on argumentation theory we have formulated our argument for this case as follows: because the feedback that the student received from the dissertation was non-legible and unfocused and because the multiple feedbacks provided by the chair were conflicting and often referred back to previous feedback changes, and since the student was not a native English speaker and had a difficult time interpreting the chair's handwritten writing, this was an inequitable situation for the student given that the role of the dissertation chair is to provide legible feedback to assist the student.

\section{Case C: The Loss of Dissertation Committee Members}

Problem: A Ph.D. student nearing completion of her dissertation lost two committee members who transferred to another university and could (or would) not finish their committee assignments. The Ph.D. dissertation chair told the student she should find replacements and that he did not have the authority to draft anyone to serve. When setting up a dissertation committee, there are two common approaches. The first and most widely used approach is where the student is in charge of soliciting committee members. In this approach, Ph.D. students normally select faculty members to serve on their dissertation committee whom they have had in courses, whom they believe to be most qualified to evaluate the subject area of the dissertation, and who do not pose any conflict of interest. The second approach is where the dissertation committee chair solicits members in conjunction with the student. However, this approach is less widely used, especially in traditional graduate schools.

In this case situation, the student visited with preferred eligible faculty members in her department. They turned her down because they were too busy or did not have the qualifications to serve on Ph.D. committees. Returning to the Ph.D. committee dissertation chair, he reiterated his position that the student was responsible for finding committee members.

Claim: This is an inequitable situation for the student because she really did not have the authority to draft any faculty member for her committee. What was recommended in this situation was for the student make a formal request, verbally and in writing, to her department head or the director of the Ph.D. program in the college or school expressing her desire to replace the two former members of the Ph.D. committee. Written documentation helps to build a case that the stu- 
dent has made a request and puts the department head or program director on notice to seek out and have the appointments made to the committee.

Advice: Even though departments may believe faculty members lack credentials or accomplishments to qualify them to serve on a doctoral committee, it is only equitable that some faculty members are recruited or assigned to allow this particular Ph.D. student to complete her dissertation and degree. There are many options administrators can exercise (and students can suggest or politely request), including using other faculty members from a university outside her school/college who can bring expertise on methodology rather than on the content/subject of the dissertation, permitting faculty members who may not have the credentials to serve in a minor role (i.e., non-readers), or finding faculty member at another university who are experts to serve on the committee.

Based on argumentation theory, our argument for this case is as follows: because the student had lost two committee members and after consulting with the dissertation chair had tried to obtain replacements and since the dissertation chair refused to help the student replace the dissertation committee members after a second consultation this was an inequitable situation for the student given the department or graduate school/college is obligated to provide the student with committee members when others leave. Despite being an inequitable situation for the student, the student should take a proactive stance by asking the department to include other faculty members and finding someone outside the university who is willing to serve on his/her committee.

\section{Case D: The No Post-Doctoral Help Dissertation Chair}

Problem: Upon completion of a Ph.D. and successfully defending the dissertation, the student asked his dissertation chair to jointly assist him in revising/reshaping his dissertation for journal publication purposes. The dissertation chair informed the student that he had no interest in further research activities with the student. The dissertation chair simply did not wish to help the student develop his dissertation research for publication as a journal article. The quality of the dissertation, which reportedly was superb, did not appear to be a factor in this decision.

Claim: Regardless of his reason for not offering assistance, this is an inequitable situation for the student because the role of the dissertation chair is to mentor the Ph.D. student to become a fullfledged scholar and a part of that process is usually to help the student publish his dissertation research or other research (if the student wants that kind of help). It is common that the student invites the dissertation chair to participate in a subsequent journal publication of his or her dissertation because of the support and guidance the dissertation chair usually contributes during the formulation of the dissertation research. However, in some situations, it is the dissertation chair that initiates the process and encourages the student to publish the doctoral dissertation research in peer-reviewed journals and/or other academic outlets upon completion.

Resolution: In this situation, the student was advised to search out another professor at a completely different university who had a record of helpful participation in guiding young doctoral students to convert their dissertations into journal articles. As it turned out, the dissertation was eventually converted into two very successful journal publications. Another alternative for the student would have been to seek out other members of the dissertation committee.

Based on argumentation theory we have formulated our argument for this case as follows: because the student asked for further help publishing the dissertation and was denied and since the quality of his dissertation did not appear to be a factor in the decision of his chair, this was an inequitable situation for the student given the role of the dissertation chair is to mentor that student and help them publish their work. In this situation, it is suggested that students take a proactive role and seek out other professors willing to help them publish even if their chair is unwilling. 


\section{Discussion and Recommendations}

In this paper, we have attempted to develop a guide aiding Ph.D. students and dissertation committee members on program problem resolution using equity theory. To further illustrate equity theory considerations and with the use of argumentation theory, we presented a series of actual case applications that we have experienced, or been made aware of, as suggestions for potential strategies in dealing with problems in Ph.D. dissertation committees. The following are some recommendations for Ph.D. students and new or veteran dissertation committee members.

As Ph.D. students are encountering various challenges during their path to obtain the degree, they must realize that inequitable situations most likely will arise. Selecting a proper course of action to inequitable situations may quickly alleviate the situation and either resolve it or lead to potential options that eventually provide resolution. Doctoral students should also be aware that some ground work is needed before approaching a potential dissertation chair to better understand the committee chair's personality, work habits, and expertise. It's unwise for a student to approach potential dissertation chairs without learning about their research publications and taking course(s) with them, as well as understanding more about their personal and scholarly characteristics. Grover and Malhotra (2003) developed a valuable model for students to better assess their personal interaction style and match it with that of a potential committee member to ensure proper dissertation success. Davis and Parker (1997) also outlined some very valuable suggestions on the selection of dissertation committee chairs and advisors as well as guidance of "dos" and “don'ts" when it comes to interacting with dissertation committee members. We recommend that students spend the time to fully study such important issues before placing themselves in a deadlock with their dissertation committee chair and/or members due to an inequitable situation. Specifically:

1. Have you taken a course with the professor you're approaching to chair your dissertation committee (Davis \& Parker, 1997, p. 27)?

2. Have you read published research that the professor you're approaching has published (Davis \& Parker, 1997, p. 27)?

3. What do you know about the personality and communication skills/habits of the professor you're approaching to chair your dissertation (Davis \& Parker, 1997, p. 27)?

For those who are new to mentoring Ph.D. student degree programs, it takes a wide-range of skills to serve as a Ph.D. committee chair. Sadly, few schools offer courses to teach those skills. Universities assume new committee chairs just know how to mentor students. For those new to mentoring Ph.D. students here are some related principles based on this paper:

1. Be willing to serve as an "academic mother or father" figure. Regardless of how many Ph.D. students choose you or you are assigned, you must treat each as unique and special as you would a child growing up under your tutelage. You must be understanding or tough like a parent when it is needed. If you're not up to that kind of relationship role, let your department chair know your limitations to help guide you or so a better assignment can be made. Not all professors are equipped to be committee chairs but most all can serve as members of a committee.

2. Understand the workload placed on the student and make it reasonable. One size does not fit all when it comes to doctoral studies because of the diverse abilities of Ph.D. students. Determine their strengths and build on them early in their program for a good beginning. If needed, direct them to take appropriate supplemental courses and/or self-training sessions to address observed weaknesses. Given that students are doing their jobs right, your job is to get them through the program, not kill them off! 
3. Understand your time commitment in mentoring students and do not overdo it. Committee chairs all have to keep up their research, service, and teaching. Do not take on too many Ph.D. committee assignments in the beginning of your mentoring career. Communicate excessive load requirements to superiors before trouble starts and notify students that it's unfair for them if you take on too many committee assignments. Offer candid advice on whom they can approach instead and what other courses of actions they can use to approach someone else.

4. Monitor student progress and make sure the impact of your feedback on a dissertation is registering with the student. Watch for signs that nothing is getting done on the dissertation, as it may be a communication problem and not the student's fault. If students become non-responsive on correcting their dissertations find out why quickly and address the issue. A recommended approach is to ensure proper written communication via email or other digital medium, while requiring the student to produce a document of revisions (abbreviated as DoRs) is valuable to ensure they are addressing all comments provided. This document also helps students to segment their work, and if clarifications are needed they can be addressed on a small number of comments.

5. Anticipate and plan contingencies for changes in the membership of Ph.D. committees. It is good policy to have at least one faculty member that can be called to fill in for a committee member who drops from a student's committee. Ph.D. programs are multi-year projects and many factors can necessitate a member of a committee to leave. Having a predetermined backup member is just good contingency planning.

6. Understand a Ph.D. committee role may become a long-term relationship with your student. An academic mother or father does not abandon their children once they are grown, nor should a Ph.D. committee chair. They should take a continued interest in mentoring them through cycles of promotion and publication efforts as they proceed to higher ranks, if the students request such attention.

For those who have served on Ph.D. committees, this paper serves to remind them what the role of a dissertation chair in the completion of a student's degree is. This service is often characterized as a "giving birth" event. When accomplished with equitable interplay, the results can be as professionally rewarding as having helped a young person start out in life or seeing your own child finishing a grade in elementary school. Dissertation chairs must remember that doctoral students have rights and need the nurturing support of a mature faculty member well beyond their Ph.D. education period. Faculty should try to establish an equitable relationship with their students that seeks to extend over many years. Students should remember to communicate and work

with their dissertation chair in meeting expectations. Students should view the role of the dissertation chair as a long-term mentor who has freely given time and effort to help them in their careers.

\section{References}

Adams, J. S. (1965). Inequity in social exchange. In L. Berkowitz (Ed.), Advances in experimental social psychology (pp. 267-299). New York: Academic Press.

Ambler, T., Styles, C., \& Xiucun, W. (1999). The effect of channel relationships and guanxi on the performance of inter-province export ventures in the People's Republic of China. International Journal of Research in Marketing, 16, 75-87.

Blair, J. A., \& Johnson, R. H. (1987). Argumentation and dialectical. Argumentation, 1, 41-56.

Blevins-Knabe, B. (1992). The ethics of dual relationships in higher education. Ethics \& Behavior, 2, 151163. 
Brass, D. J., Butterfield, K. D., \& Skaggs, B. C. (1998). Relationships and unethical behavior: A social network perspective. Academy of Management Review, 23, 14-31.

Carrell, M. R., \& Dittrich, J. E. (1976). Employee perceptions of fair treatment. Personnel Journal, 55, 523-524.

Carrell, M. R., \& Dittrich, J. E. (1978). Equity theory: The recent literature, methodological considerations, and new directions. Academy of Management Review, 3, 202-210.

Carter, B., \& Whittaker, K. (2009). Examining the British PhD viva: Opening new doors or scarring for life? Contemporary Nurse: A Journal for the Australian Nursing Profession, 32, 169-178.

Cassuto, L. (2010). The dissertation student who won't finish. Chronicle of Higher Education, 57, A47A49.

Chan, A.W. (2008). Mentoring ethnic minority, pre-doctoral students: An analysis of key mentor practices. Mentoring \& Tutoring: Partnership in Learning, 16, 151-176.

Cosier, R. A., \& Dalton, D. R. (1983). Equity theory and time: A reformulation. Academy of Management Review, 8, 311-319.

Dalton, D. R., \& Todor, W. D. (1982). Antecedents of grievance filing behavior: Attitude/behavioral consistency and the union steward. Academy of Management Journal, 25, 158-169.

Davis, G. B., \& Parker, C. A. (1997). Writing the doctoral dissertation: A systematic approach (2 ${ }^{\text {nd }}$ ed.). Hauppauge, NY: Barrons Educational Series.

Driver, R., Newton, P., \& Osborne, J. (2000). Establishing the norms of scientific argumentation in classrooms. Science Education, 84, 287-312.

Grover, V. (2007). Successfully navigating the stages of doctoral study. International Journal of Doctoral Studies, 2, 9-21. Retrieved from http://www.ijds.org/Volume2/IJDSv2p009-021Grover21.pdf

Grover, V., \& Malhotra, M. K. (2003). Interaction between a doctoral student and advisor: Making it work! Decision Line, 1, 16-18.

Homans, G. (1961). Social behavior: Its elementary forms. New York: Harcourt, Brace and World.

Johnson, W. B. (2010). Student-faculty mentorship outcomes. In T. D. Allen \& L. T. Eby (Eds.), The Blackwell handbook of mentoring: A multiple perspectives approach. Malden, MA: John Wiley\& Sons.

Johnson, W. B., \& Huwe, J. M. (2003). Getting mentored in graduate school. Washington, DC: American Psychological Association.

Kalbfleisch, P. J. (1997). Appeasing the mentor. Aggressive Behavior, 23, 389-403.

Kram, K. E. (1985). Mentoring at work: Developmental relationships in organizational life. Glenview, IL: Scott, Foresman and Company.

Leung, T. K. P., Heung, V. C. S., \& Wong, Y. H. (2008). Cronyism: One possible consequence of guanxi for an insider and how to obtain and maintain it. European Journal of Marketing, 42, 23-34.

Leventhal, G. S., Allen, J., \& Kemelgor, B. (1969). Reducing inequity by reallocating rewards. Psychonomic Science, 14, 295-297.

Levy, Y., \& Ellis, T. J. (2006). A systems approach to conduct an effective literature review in support of information systems research. Informing Science: The International Journal of an Emerging Transdiscipline, 9, 181-212. Retrieved from http://www.inform.nu/Articles/Vol9/V9p181-212Levy99.pdf

Locke, E. A. (1976). The nature and causes of job satisfaction. In M. D. Dunnette (Ed.), Handbook of industrial and organizational psychology (pp. 1297-1349). Chicago: Rand McNally.

Lovett, S., Simmons, L. C., \& Kali, R. (1999). Guanxi versus the market: Ethics and efficiency. Journal of International Business Studies, 30, 231-248. 
McWilliam, E., Singh, P., \& Taylor, P.G. (2002). Doctoral education, danger and risk management. Higher Education Research \& Development, 21, 119-129.

Miller, J. R. (2010). Lawsuit claims college ordered student to alter religious views on homosexuality, or be dismissed. Retrieved September 1, 2010 from: http://www.foxnews.com/us/2010/07/27/georgiauniversity-tells-student-lose-religion-lawsuit-claims/

Mobley, W. H., Griffeth, R. W., Hand, H. H., \& Meglino, B. M. (1979). Review and conceptual analysis of the employee turnover process. Psychological Bulletin, 86, 493-522.

Muchinsky, P. M. (1977). Employee absenteeism: A review of the literature. Journal of Vocational Behavior, 10, 316-340.

Muchinsky, P. M., \& Tuttle, M. L. (1979). Employee turnover: An empirical and methodological assessment. Journal of Vocational Behavior, 14, 43-77.

Nesbit, P. L., \& Burton, S. (2006). Student justice perceptions following assignment feedback. Assessment \& Evaluation in Higher Education, 31, 655-670.

Patchen, M. (1961). The choice of wage comparisons. Englewood Cliffs, NJ: Prentice Hall.

Paludi, M. (1990). Creating new taboos in the academy: Faculty responsibility in preventing sexual harassment. Initiatives, 52, 29-34.

Porter, L. W., \& Steers, R. M. (1973). Organizational work, and personal factors in employee turnover and absenteeism. Psychological Bulletin, 80, 151-176.

Rest, J. R. (1986). Moral development: Advances in research and theory. New York, NY: Praeger.

Sanchez, R. (December, 1997). Applicant's challenge emerges as pivotal affirmative action case. Washington Post, p. A01.

Schniederjans, M. J. (2007). A proposed Ph.D. student bill of rights. International Journal of Doctoral Studies, 2, 1-8. Retrieved from http://www.ijds.org/Volume2/IJDSv2p001-008Schniederjans22.pdf

Shambaugh, R. N. (2000). Reframing doctoral programs: A program of human inquiry for doctoral students and faculty advisors. Innovative Higher Education, 24, 295-308.

Smallwood, S. (2004). High attrition from Ph.D. programs is sucking away time, talent, and money and breaking some hearts, too. Chronicle of Higher Education. Retrieved January 16, from http://chronicle.com/weekly/v50/i19/19a01001.htm

Steers, R. M., \& Rhodes, S. R. (1978). Major influences on employee attendance: A process model. Journal of Applied Psychology, 63, 391-407.

Telly, C. S. French, L., \& Scott, W. G. (1971). The relationship of inequity to turnover among hourly workers. Administrative Science Quarterly, 16, 164-171.

Tornow, W. W. (1971). The development and application of an input-outcome moderator test on the perception and reduction of inequity. Organizational Behavior and Human Performance, 6, 614-638.

Toulmin, S. (1958). The uses of argument. Cambridge: University Press.

Wicker, A. A., \& Bushweiler, G. (1970). Perceived fairness and pleasantness of social exchange situations: Two factorial studies of inequity. Journal of Personality and Social Psychology, 15, 63-75.

Williams, J. M., \& Colomb, G. G. (2003). The craft of argument. (2nd ed.). New York, NY: Longman.

Zalk, S., Paludi, M., \& Dederich, J. (1990). Women students' assessment of consensual relationships with their professors: Ivory power reconsidered. In E. Cole (Ed.) Sexual harassment on campus: A legal compendium (pp. 103-133). Washington, DC: National Association of College and University Attorneys. 


\section{Biographies}

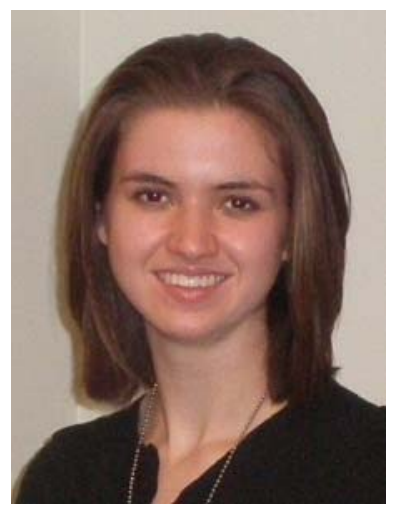

Dara G. Schniederjans is a Ph.D. candidate in Operations Management at the Rawls College of Business, Texas Tech University in Lubbock, Texas. Her research interests include business ethics and trust research, social issues in supply chain management and information systems. She has published in journals like Journal of the Operational Research Society, Quality Management Journal and Global Studies Journal. She is the co-author of the book, Topics in Lean Supply Chain Management and co-editor of Outsourcing Management Information Systems.

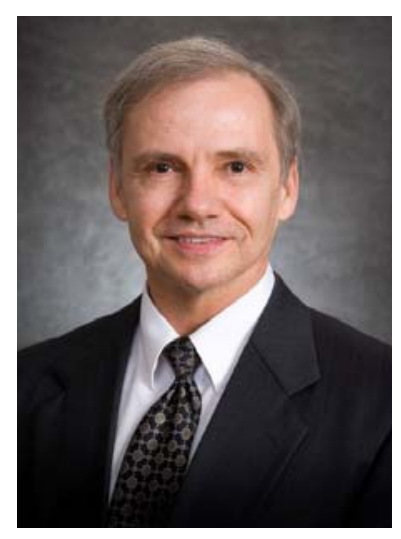

Marc J. Schniederjans is the C. Wheaton Battey Distinguished Professor of Business in the College of Business Administration at the University of Nebraska-Lincoln. He has served on doctoral program committees for 30 years. He currently teaches courses in supply chain management and decision sciences and has authored over 110 journal articles covering a variety of topics in theory, application and case studies in management. He has also authored or co-authored 20 books in the fields of management. Schniederjans research has also garnered awards from the Decision Science Institute and the American Production and Inventory Control Society, and he is a fellow of the Decision Sciences Institute.

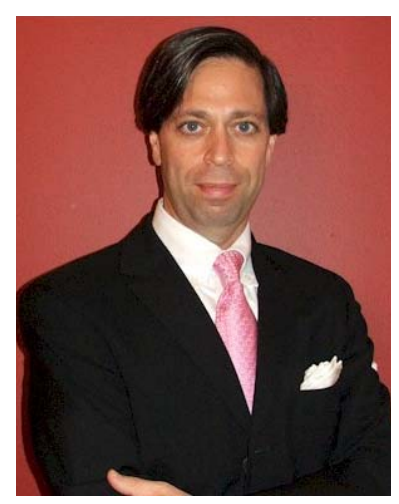

Yair Levy is an associate professor at the Graduate School of Computer and Information Sciences at Nova Southeastern University. During the mid to late 1990s, he assisted NASA to develop e-learning systems. He earned his Bachelor's degree in Aerospace Engineering from the Technion (Israel Institute of Technology). He received his MBA with MIS concentration and Ph.D. in Management Information Systems from Florida International University. His current research interests include cognitive value of IS, of online learning systems, effectiveness of IS, and cognitive aspects of IS. He is the author of the book "Assessing the Value of e-Learning systems." His research publications appear in the IS journals, conference proceedings, invited book chapters, and encyclopedias. Additionally, he chaired and co-chaired multiple sessions/tracks in recognized conferences. Between 2006 and 2011, he served as the founding Editor-in-Chief of the International Journal of Doctoral Studies (IJDS). Moreover, he is serving as an associate editor and a member of editorial review or advisory board of several refereed journals. Additionally, he has been serving as a referee research reviewer for numerous national and international scientific journals, conference proceedings, as well as MIS and Information Security textbooks. He is also a frequent speaker at national and international meetings on MIS and online learning topics. To find out more about him, please visit his site: http://scis.nova.edu/ levyy/ 